\title{
CSF2RA wt Allele
}

National Cancer Institute

\section{Source}

National Cancer Institute. CSF2RA wt Allele. NCI Thesaurus. Code C51348.

Human CSF2RA wild-type allele is located in the vicinity of Xp22.32 and Yp11.3 and is approximately $41 \mathrm{~kb}$ in length. This allele, which encodes granulocyte-macrophage colony-stimulating factor receptor subunit alpha protein, plays a role in the proliferation, differentiation and activation of granulocyte and macrophage hematopoietic cells. 